\title{
SELLING ITALY BY THE SOUND \\ Cross-cultural interchanges through cover records
}

\author{
by Paolo Prato
}

\begin{abstract}
Since the beginning of modern canzone, cover versions have represented a shortcut to import and export songs across national borders. By breaking language barriers, these records have played the role of ambassadors of Italian music abroad and, viceversa, of Anglo-American music at home.

Although cover records mania boomed especially in the sixties, the history of Italian popular music is disseminated by such examples, including exchanges with French and Spanish speaking countries as well, but not only. After reflecting on the nature of 'cover' and offering a definition that includes its being a cross-cultural space most typical of Italy and other peripheral countries in the age of early contacts with pop modernity, the paper focuses on the economical, aesthetic and sociological paradigms that affect the international circulation of cover records and suggests a few theoretical explanations that refuse the obsolete 'cultural imperialism' thesis in favour of a more flexible view hinged upon the notion of 'deterritorializazion'. In the final section the paper provides a short history of Italian records that were hits abroad, decade by decade, and ends up with highlighting those artists that played the role of cultural mediators between Italy and the world.
\end{abstract}

During a talk in the backstage of his first Sanremo Festival, in the year 1964, Frankie Laine was asked by a journalist who were his favourite Italian singers. 'Tony Bennett and Perry Como' said he. 'I said Italian', insisted the interviewer. 'But they are Italian', replied the Italian-American artist born as Frank Paul Lo Vecchio. How to blame the 50 year old pop star, if the two people he had mentioned were called Anthony Dominick Benedetto and Pierino Como and were the only Italian singers he knew? By that time, as a matter of fact, no Italian singer could claim to have reached worldwide fame, save maybe for the meteor Domenico Modugno whose 'Volare' had been however a sort of 'one chord wonder' in 1958, with no sequel at all. The only international stars of the early 1960s coming from Italy were movie stars, from Sofia Loren to Federico Fellini, from Marcello Mastroianni to Sergio Leone. Music was far behind. If Cinecittà studios, the poetics of neo-realism, comedy Italian style and the beginning of spaghetti Western are still judged by historians as some of the most advanced experiences in the cinema of the 1950s and the 1960s, giving way to fecund international exchanges on a productive and aesthetic level, canzone italiana was hopelessly provincial and domestic. Its major institution, the Sanremo Festival (1), had been long oriented towards preserving the purity of Italian singing, acting like a Ministry of Fine Arts. But in 1964 things began to change: taking example from the world of football, where foreigners had been playing in Italian teams for years, the competition opened to foreign interpreters. Only one year before, domestic politics had witnessed a remarkable change with the advent of the first centreleftist government of the brief Republican history. 'From today everyone is more free' titled the Socialist daily paper L'Avanti! At Sanremo it seemed that the same wind of liberty had started to blow when the first Foreign Legion came over from the Americas to sing brand new songs that most of them would have soon forgotten: their names were Frankie Laine, Frankie Avalon, Paul Anka, Gene Pitney and Bobby Rydell, who headed the teen idol squad, followed by outsiders such as soul man Ben E. King, the Chilean Antonio Prieto and the Cuban brothers Los Hermanos Rigual. An exciting festive spirit soared on this New Babel but the poor familiarity with English and the lack of information about the guests made it the Festival of blunder, the most recurrent form of communication on stage when foreigners were presented by the compere's assistant Giuliana 
Lojodice whereas artists acted like Totò and Peppino to grips with tourists in a famous movie gag. Foreign interpreters were humble and professional enough to respect the rules of the Italian contest and give their best to win. It was fun to hear Gene Pitney sing 'Quando vedrai la mia ragazza' after hearing the same song by the voice of his Italian partner Little Tony, or 'Ogni volta' by Paul Anka after Roby Ferrante's interpretation. The winner was the sixteen year old Gigliola Cinquetti, coupled with French Patricia Carli and her song 'Non ho l'età' became an international hit after winning the Eurofestival contest as well.

That was the beginning of a most fertile season in the mobilization of music artefacts and tastes, where cover records played a crucial role. Summer 1967, the so called Summer of Love: just imagine a teenage couple in London or Bristol dancing to the record that has topped the domestic charts for the whole months of June and July, 'A Whiter Shade of Pale' by the Procol Harum. In the same days in Turin or Florence, imagine a teenage couple dancing to another record, this time a hit in Italy: 'Senza luce', by a group named Dik Dik. Their performance might have been identical for they were virtually dancing to the same record: as a matter of fact the music was the same, although performed by different bands; the lyrics, instead, were different because different was the language employed. English in the first case, Italian in the second.

Growing up in Italy's mid-sixties meant - among other things - being exposed to the same new music which had come to hegemonize all of Western young ears: beat, folk-rock, the Beatles, Motown and so on. The ways in which that music was listened to and the settings in which it was used were probably similar even if at different latitudes and sides of the Atlantic: mono record players and low-fi loudspeakers squeaking from smoky basements where the birthday party took place... Remember? Does it mean anything to anyone?

That 'revolution' in sound was however hardly felt as a fashion imported from abroad: on the contrary, most of the hip records were sung in Italian, so that an entire generation, including the author of this article, grew up believing that 'Che colpa abbiamo noi', 'Sognando California' or 'Ragazzo triste' - just to pick up three titles at random - were great Italian songs. Only a few years after, and only if you had some good reasons to go back to those songs, you might have discovered that 'Che colpa abbiamo noi', which gave immortality to a group of British immigrants based in Italy called the Rokes, was the Italian version of 'Cheryl's Going Home', recorded by Bob Lind and the Blues Project. And you might discovered as well that 'Sognando California' - with its epochal beginning 'cielo grigio su, cielo grigio su / foglie gialle giù, foglie gialle giù' - was nothing more than a rough translation of Mamas \& Papas' big hit 'California Dreamin '. And, finally, you might have been disappointed by discovering that the career of Patty Pravo, the teen-idol identified with the mark of 'angst and rebellion', was shaped on imported patterns: her debut single 'Ragazzo triste' was the cover version of 'But You're Mine', by Sonny \& Cher.

An entire season evolved under the sign of what I like to call the Big Cheat or, if you prefer, The Great Cover Version Swindle long before the Sex Pistols came to rock the house ... The thing is that at the time, according to a well known theory which states that cultural goods can be reappropriated in many different ways, originate new meanings or follow unexpected paths, nobody really felt cheated. Viceversa, the very modernization of Italian canzone mostly occurred thanks to this 'Big Cheat' and it does not really matter if 'Che colpa abbiamo noi' was originally an American song titled 'Cheryl's Going Home'. The history of popular music tells us that only the former survived: the original record by Bob Lind (B-side of 'Elusive Butterfly', \#5 in UK) and its cover by the Blues Project remained almost unknown both in US nor in UK, whereas the Rokes' cover went number 3 in Italy pioneering one of the most brilliant careers in the sixties (2). 'Che colpa abbiamo noi', with its overt message epitomized even in the title ('what should be our fault?') became a generation anthem bound to last over time, if you think that still in 2003 that song gave the title to a movie on 
the youth condition in Italy. Why has it been so? Why was the same song nearly a flop in its country of origin and a big hit turned into an evergreen in Italy? The answer probably lies in the words: Mogol (nickname for Giulio Rapetti), the man who wrote the lyrics of 'Che colpa abbiamo noi', did not make a simple translation of Bob Lind's song but chose to write a totally different text. 'Cheryl's Going Home' was a song of love and despair. Its Italian version became a protest song, but with tones that were soft enough to be accepted by a mainstream audience willing to emancipate and, at the same time, to satisfy a youth audience who dared not too much.

Since the beginning of modern canzone, cover versions have represented a shortcut to import and export songs across national borders. By breaking language barriers, these records have played the role of ambassadors of Italian music abroad and, backwards, of Anglo-American music at home. Although the fad of cover records flourished especially in the sixties, the whole history of Italian popular music is disseminated by such examples, including exchanges with French and Spanish speaking countries as well, but not only. After providing a more narrow definition of 'cover record' as a cross-cultural space most typical of Italy and other peripheral countries in the pre-globalization age, in this article I will focus on the phenomenon mainly from a historical and sociological point of view, dealing both with Italian covers of foreign hits and foreign covers of Italian hits. The history of cover records - a much neglected aspect of popular music production in Italy - in a sense mirrors the history of cross-cultural interchanges and the fight for domination in the planetary market place, thus providing some good arguments for outlining a new musical geopolitics. Cover records did count in a time in which cultural products were mostly confined to domestic market. Their decline began when people started buying the original versions of hit songs. This epochal turn is eventually characterized as a paradigm shift from (old) exoticism to (new) globalization.

Before dealing with the cultural implications of this turn and reviewing the history of cover records in Italy, I would like to briefly explore the nature of 'cover' itself and offer a few reflections.

\section{A theory of 'coverability'}

Is it possible to cover any song? And if not, what kind of songs offer more resistance and what others seem more apt to be covered? I will try to give some answers to these questions that involve the very nature of popular music and maybe not only that.

Let me start with an attempt definition of the object: 'the term cover refers to the second version, and all subsequent versions, of a song, performed by either another act than the one that originally recorded it or by anyone except its writer' (Pareles-Romanowski 1983). This definition does not include the possibility of a language other than the original but, technically, it works the same.

A more articulate definition comes from the Encyclopedia of Popular Music of the World where 'cover version' is given a different meaning according to five musical and historical contexts: commercial music before rock, rock 'n' roll, rock, rock homage and sampled music. Although the topic of this paper crosses all XIXth century's decades, the only reference to foreign language versions is made in the first case, that of commercial music before rock. Just a few lines in the end remind the reader that 'cover versions can also be part of an industry-driven strategy of localization, in which a song popular in a foreign country is adapted for a domestic market' and quote as an example a French version of Chubby Checker's 'Let's Twist Again' (Keightley 2003, pp.614-617). Too little to understand and weigh the crucial role that cover versions had in the making of a modern musical mentality outside USA and UK. The writer of the entry has developed his topic exclusively from an Anglo-American perspective, which made him totally miss the point I am trying to make: in my view, a cover version is a cross-cultural space most typical of Italy and other 
peripheral countries in an age of transition to full modernity. More specifically, the 'golden age' of cover version were the sixties, a decade in which the music industry - following a more general trend concerning a new cycle in consumptions and a worldwide thrust to assimilate products, styles and behavior habits coming from the USA - capitalized the needs of the first affluent generation by addressing them on a new technological medium: the single $45 \mathrm{rpm}$ record. The cover boom was therefore the result of a multiplicity of factors: economical, social and cultural. For the generation grown up in the sixties, in virtually every Western country the cover versions were the ticket to Paradise, if by Paradise it is meant the chance of sharing a feeling of modernity not only with schoolmates but also with buddies of other countries, who would speak foreign languages but know exactly the same songs, dance to the same rhythms, cheer the same artists or the same typologies of artists. If you travelled to Brazil you did not find only bossa nova or samba. You could listen to a local version of the Yardbirds' 'For Your Love' by Renato e seus Blue Caps, or to the Monkees' hit 'Last Train to Clarskville' by the Sunshines (3). And if you travelled to Japan you could, surprisingly, find local versions of Italian hits such as 'Renato' (a hit for Mina, covered by Mieko Hirota), 'Una lacrima sul viso' (a hit for Bobby Solo, covered by Mari Sono) or 'Arrivederci' (a hit for Umberto Bindi, covered by the Peanuts) (4).

Now I would like to explore a little bit more in detail the notion of 'coverability', and in particular what can be covered and why. It's easier to cover songs conceived in the classical/pre-rock vein, with a recognizable structure and melody, songs that make sense out of a written score rooted in the Tin Pan Alley tradition but also in the beat explosion of the 1960s. You cannot cover Jimi Hendrix's 'Voodoo Chile' or the Led Zeppelin's 'Whole Lotta Love', and in fact ther are no covers available of the above mentioned and of most of their repertoires except for parodies, such as in the case of The Temple City Kazoo Orchestra's rendition of 'Whole Lotta Love', performed with kazoos. But you can cover the Beatles, except for 'Revolution n.9' maybe.

A song that has a strong identity on sheet, before than on record, seems to have more chances to be covered: being available in form of notation and not only as recorded sound is a guarantee of a higher degree of rationality (in the sense that Max Weber would give to this notion) and the more its written form is accurate (i.e. it gets near to its performed version), the more rational, abstract, universal is the song. In other words, the more its performance can do without the original recording to be succesfully covered (it is the case of all classical music), the more it can be reproduced in another language too by simply changing the lyrics. This was the way popular music functioned for a long period of time, say until the early 1960s: cover bands, dance orchestras and combos all relied upon a written text (sheet, score), rather than on records, to perform their music. It was a time dominated by arrangers, then almost totally disappeared with the arrival of rock.

Rock represented a leap back into orality and performance: in terms of mainstream sociology, rock leaned towards 'particularism' instead of 'universalism' for its sound, its very 'core' was in the hic et nunc of a particular performance made by those musicians and not by others. As such, a rock song was not so replicable as a pop song. In this respect, rock (and the whole afro-american tradition, where rock was partially rooted) resuscitated what Walter Benjamin called 'aura', i.e. something ineffable tied to the uniqueness of the art product and/or its acting and something on which rock built its ideology of authenticity. No wonder, therefore, that there are no classic rock songs covered in Italian. No Cream, no Pink Floyd, no Genesis... but plenty of Beatles' and Motown song, in a few cases sung directly by the original artists such as Stevie Wonder, the Supremes, the Temptations, the Four Tops, Edwin Starr, Smokey Robinson and Jimmy Ruffin. It happened only once with the Rolling Stones ('Con le mie lacrime', a cover of 'As Tears Go By'), The Procol Harum ('Il tuo diamante', a cover of 'Shine On Brightly', 1968) or David Bowie ('Ragazzo solo ragazza sola', a cover of 'Space Oddity', 1969) but it was the rule for people like Neil Sedaka, Paul Anka, Gene Pitney, Petula Clark, Sandie Shaw, Tom Jones or Pat Boone, who in 
the mid sixties enjoyed a big success in Italy and often topped the charts with Italian versions of their original hits. The same occurred to an even greater number of French singing artists such as Richard Anthony, Antoine, Alain Barrière, Dalida, Michel Delpeche, Nino Ferrer, Françoise Hardy, Johnny Halliday, Michel Polnareff and Spanish and Latin American artists such as Chico Buarque de Hollanda, Roberto Carlos, Los Hermanos Rigual, Antonio Prieto and Toquinho. And it was also a good test for more occasional acts such as Cher, Shirley Bassey, Ben E.King, Bobby Rydell, Mary Hopkin, Udo Jurgens, Dusty Springfield, the Sandpipers, all of whom recorded in Italian and most came to participate in the Sanremo Festival of Canzone Italiana - for a few years a real international arena which hosted the best selling artists in the world.

In more recent times also Sting and Michael Bolton have recorded in Italian thanks to friends and mediators such as Zucchero or Luciano Pavarotti, whereas Eros Ramazzotti has recorded duets with many international stars including Tina Turner ('Cose della vita' - 'Can't Stop Thinking Of You'), Cher ('Più che puoi'), who got back to in Italian in several occasions, after her debut in 1967, and Anastacia ('I Belong to You' - 'Il ritmo della passione'). Last but not least, Laura Pausini got a Grammy Award in 2006 as Best Latin Artist for her album Escucha in Spanish (5), whereas the Israeli artist Noah participated in the Sanremo Festival of 2006 singing in Italian together with Carlo Fava and the Solis String Quartet (6).

The international record market experienced a dramatic development in the last few decades, which has brought to a radical remapping of its geography, logics and opportunities. In order to understand what lies under the practice of cover and its slow but irreversible decline, it is necessary to ask a few questions of theoretical nature. Theferore I would like to go back to an explicative theory which has been long applied to cultural products but which does not seem to fit in cases like this.

\section{From cultural imperialism to deterritorialization}

Reflecting upon cross-cultural interchanges, it is almost inevitable to refer to a theory which seemed to explain the geopolitics of music until a few years ago: the so called 'cultural imperialism thesis'. If we go back to the Italian media literature of the 1960s, for example, we come across a first relevant statement by Francesco Alberoni, who saw mass culture stratified in five major areas, at a planetary level:

1. the cultural centre (USA), characterized by a integration of pleasure and sense of duty;

2. an area of high acculturation (i.e. West Germany) which contained zones not influenced by by the centre but where the USA are seen as a positive model;

3. an area of partial acculturation (i.e. Italy, Japan), where mass culture has an external origin and the USA are a controversy model;

4. an area of disintegration (i.e. many Latin American countries) where mass culture, originated outside, starts up a revolution in expectations ending up with a disorganization of the system;

5. the area of new oppositional syntheses (i.e. USSR, China) where mass culture is partially assimilated and partially fought, and the USA are a negative model (Alberoni 1966, p.123).

Twenty years later the record industry applied a similar theory to understand the penetration in world markets:

1. The USA. If a record is a hit in the USA, there are good chances that it becomes a hit in most other markets. 
2. The United Kingdom. Its influence is second only to the American one and if a record is a hit in the UK, it will probably be hit in most countries except for the USA and Japan.

3. West Germany. It's the only influential country left: a hit in BRD may be a hit in most European countries except for the UK.

4. The rest of the world. Here, the relationships among markets must be examined case by case. For example, Spain may influence South America except for Brazil; a hit in the Netherlands may become a hit in Germany, and so on.

This explanation of how markets would influence each other had undoubtedly many faults, primarily because that of music is a typical turbulent market, i.e. very little predictable.

But it made clear, however, the notion of 'cultural imperialism' as applied to mass media and, more specifically, to sound artefacts. This media imperialism was defined as 'the process whereby the ownership, structure, distribution or content of the media in any country are singly or together subject to substantial external pressure from the media interests of any other country or countries, without proportionate reciprocation of influence by the country so affected' (Boyd Barrett 1977, p.116-135). The cultural imperialism thesis maintained that in many parts of the world, local cultures - identified as 'authentic' - were menaced by the indiscriminated flow of low value products coming mostly from the USA. This forced modernization brought about the shaping of local institutions to correspond to, or even promote, the values and structures of the dominating center of the system. (Schiller 1976).

Yet, a critical view counterposed that this notion was oversimplified, for it does not take into account the role of strong regional exporting countries such as Mexico and Argentina, for example, with regard to their neighbouring countries, or Egypt with regard to the Arab world, or India with regard to many Asian and African countries. The list could be increased by adding exporting countries such as the former USSR, with regard to East European countries, Sweden, with regard to Scandinavia, Spain, France and Italy (Tunstall 1977, p.62). Moreover, not every product coming from the centre has to be regarded as disruptive of the local culture. First because the very notion of cultural identity as authentic is highly suspect, being often taken as nostalgic and/or reactionary (Garnham 1984, p.6). Second because the first targets of those products are the young who, since the fifties, have been using foreign music 'as a means to distance themselves from a parental 'national' culture' (Laing 1986, p.338).

The theory which saw a clear contraposition between products and markets of central and peripheral countries was 'probably very applicable to the time in which it was proposed, the 1970s; with the advent of advanced communication technologies that allow for a multi-directional as opposed to a uni-directional flow of information between countries, cultural imperialism is no longer a useful framework for explaining the same phenomena...' (White 2001, p.9). In a global world, popular culture dynamics take the most unexpected forms. How to explain, i.e., the incredible success that many Italian products and artists have experienced in Japan, where there are no Italian communities, no immigrants, only a few business persons ? Canclini suggests to erase the distinction between centre and periphery and use instead the notions of 'circuit' and 'frontier', more suited to explain the dynamics of cultures that appear to be more and more hybrid (7). At the same time, it makes no more sense the distinction between 'hegemonic' and 'subaltern' which was implied by the cultural imperialism thesis. What we are facing here is not a vertical flow from a class to another inside the same territory (geographic, political) but a horizontal flow from one place to another. In this passage hegemony is lost and frayed and tends to reconstitute itself as 'new hegemony' rather that as 'subalternity' (Canclini 1990). Borrowing from Canclini and Appadurai, I would speak of deterritorialization and reterritorialization to better explain why, for example a good portion of our popular music is 'big in Japan', from Claudio Villa to prog rock for collectors, from techno pop to local artists playing in Italian (e.g. Cioccolata) (8). Nothing is more distant than the 
notions of 'imperialism' or 'homegeneization' (both strictly tied to the notion of 'Americanization') to make sense out of these cultural trends. What is imported in other countries tends to be assimilated and appropriated in different forms and to produce practices and artefacts that may not exist in the original country (Appadurai 1996).

With respect to the interaction between peripheral and core popular music production (keeping in mind that the 'periphery' exists in virtually every country as well as nationally on a world scale), some observators hold that there are three broad stages of musical evolution: 'a) learning to understand another type, style, of music; b) peripheral repetition of that dominant music, and c) peripheral creation of original music that combines indigenous and 'Other' musical elements' (9). The 'cover' fever belongs to the second stage and is clearly associated to repetition, emulation and the like: ways to appropriate a foreign style which was dominant in virtually all the Western world.

As put by Roger Wallis and Krister Malm, 'the world had been flooded with Anglo-American music in the fifties and sixties' and only in the late sixties, almost everywhere local musicians began to develop their own style paving the way to national rock. The Swedish rock movement exploded around 1970, with thousands of gropus singing in Swedish. The same took place in Wales, with musicians adopting Welsh as official language in their songs. The first pop record sung in Siinhala was released in Sri Lanka in 1969 whereas in numerous African countries (e.g. Kenya, Tanzania) jazz and pop bands began to speak their languages. 'After almost ten years of copying the Beatles, Elvis or Chubby Checker, musicians in the small nations started trying to develop their own national forms of popular music' (Wallis-Malm 1984, p.303). The cover phenomenon in Italy takes over and develops in those ten years or so characterized by 'imitations of transnational pop and rock music by local groups' which, according to Wallis and Malm, is a common feature to the nine small countries taken into consideration in their seminal study, but which seem to apply to other countries as well, Italy included.

Let us look briefly to some other countries that in the 1960s were in conditions similar to Italy, in order to make further comparisons. Take Greece, for example: rock groups established in the early 1970s and played their own music along the lines of Anglo-American pop-rock, singing in English. This represented a significant break with the tradition of singing in Greek or translating foreign songs into Greek (e.g. through the practice of covers). But that 'borrowed' rock did not become very popular: on the contrary people sticked to the 'real' original rock.

Take a few Eastern European countries such as Estonia, where in the 1960s 'everyone wanted to copy the Beatles and other groups' and Western hits in general or Hungary, where hundreds of amateur beat groups tried to reproduce current British and North America hits in high school, university and company clubs (10). The cover mania was significant in countries that were officially immune to Americanization, such as Bulgaria - where amateur student groups covered mostly repertoire by the Shadows, the Beatles and the Rolling Stones- or Croatia - where the 'imitative rock bands' dominated the scene before the release of the first domestic rock album in 1968 (11).

The cover mania was certainly more visible, if not significant, in those Western countries that fell directly under the Anglo-American influence in shaping their cultures, tastes and consumer's choices. Take for example Austria, where the Vienna Beatles and the Beethovens led a string of imitators, or Finland, where 'the early years of Finnish pop consisted of outright imitation and applications of Anglo-American models' and Norway - 'during the years 1960-64 numerous bands emerged covering the Shadow's music' (12). Not to speak of France, Germany and even Spain, where artists and groups produced Spanish versions of international hits, but French and Italian songs were highly successful as well (13). 
And everywhere in the non-Western world that would fall under the Western influence, music played a crucial role: for example in Hong Kong, the Chinese anomaly that wasn't part of the Cultural Revolution but looked West for its development, the young liked a music that was 'fully derivative of Western pop and rock... and the bands had all English names' (14). In South Korea the assimilation of North American popular music dates back to the 1950s, first in an imitative vein, then by appropriating an overall 'underground' style as was the case of tong-guitar singers covering Bob Dylan's protest songs (15), whereas in Malaysia the pop-yeh-yeh movement exploded in the early 1960s generating hundreds of Rolling Stones' and Cliff Richard's clones (16). A slightly different story is that of the Philippines, long dominated by the US politics and culture: along with the Anglo-American influence, the 1950s witness a significant Latin American fad (17). A few years later Beatlemania swept the country resulting in generating groups 'clearly patterned after such famous groups as the Ventures, the Dave Clark Five, the Monkees and the Rolling Stones, as well as the Beatles' (18). Covers of Western pop had been common in Singapore and Thailand since the 1950s and the Beat era was featured by copy bands like the Quests (covering only Shadows' songs), the Cyclones (Beatles) and Wilson David (Elvis Presley) - all of them from Singapore - and the Cats - from Thailand (19). Aping Anglo-American pop rock was by no means a phenomenon limited to Europe and Western-influenced Asia, but concerned Africa too: in a country such as Algeria, that musically found a very distinct way from the 1980s on, the 1960s and the 1970s were featured by 'groups with anglicized names such as the Students, the Vultures, the New Clarks' (20) whereas the major Anglo-American hits of those years were adapted for mandolin-like instruments by Mozambique's conjuntos focloricos (21). In Zimbabwe 'the mid-to late 1960s saw the rise of bands covering songs by the Byrds, Cream, the Kinks and Jimi Hendrix (22) and in the pre-fundamentalist Iran (under the Pahlavi regime) 'guitar groups and solo singers emerged in imitation of such stars as Elvis Presley and the Beatles' (23).

The case of Japan is even more striking, since the assimilation of Anglo-American popular music into the country's habits dates back to the '20s and the 1960s reveal many similarities with what happened in Italy: the long haired male groups that formed by the hundred 'initially modeled their own compositions on those of the British groups as well as copying them' and they had all English names (24). Cases apart are those regarding countries that had political relationships with Italy in their recent history, such as Greece - again - where, in the 1960s, where Italian pop ballads stood aside Anglo-American pop and rock in influencing the youth taste, although 'most of the early pop groups in Greece were very modest imitations of British and North American bands' (25).

Cover records in Italy offer just one more example of how sometimes objects do not fit into the available analytic tools on cross-cultural exchanges. Wallis and Malm classify the kinds of interaction between local and international music in four categories, none of which seems to apply to our object: the first pattern is cultural exchange, where the two cultures communicate and influence each other on the same level; the second pattern is cultural dominance, when a culture is imposed on another; the third pattern is cultural imperialism, when the dominance is augmented by the transfer of money; the final pattern is transculture, when two or more cultures blend in a new transnational culture. We can say that covers in Italy are by no means a product of cultural exchange (pattern 1) for the impact of Italian music on Anglo-American music is not comparable to its opposite; nor are they a product of cultural dominance, although it might have been the case: covers were more than often original rewritings of foreign records. We cannot then speak of cultural imperialism simply because the 'money element' is not primary: cultural imperialism adds money to cultural dominance and money here is equally parted - as far as copyright is concerned - between foreign authors/publishers and domestic lyricists (non just translators) (Wallis-Malm, 1984 p.299). As far as royalties are regarded, they went totally to domestic performers who no necessarily had 
relationships with the original record companies. Finally, cover records do not represent a transculture at all, needless to say.

Nevertheless, one more element seems to be able to explain the cover phenomenon in the 1960s and its huge impact on the young generation: those records came together with a radical innovation in media technology and in the use of mass media (26). To put it better, they were not only associated with those epochal changes but were their ambassadors: if you convinced your dad to substitute your old radio set with a brand new stereo, the first thing you wanted to play was a single in English or a beat song in Italian (mostly a cover version of a British or American hit). That gesture proved that a family battle for modernity had been won, although that did not mean you had won the war...

\section{A brief history of Italian songs covered abroad}

If Italian covers of foreign hits would make up an endless list of titles and their history would probably raise poor interest to a public of foreign readers (27), I believe it is more interesting to focus on their contrary: the more limited field of Italian songs covered abroad. The first one to cross over and become a international standard was probably 'Ciribiribin', written by Pestalozza with lyrics by Tiochet and published in 1898. It was launched by the German singer Mitzi Kirchner and recorded by Prince's Orchestra (\#3, 1911, USA), Grace Moore (in the movie One Night of Love, 1935 \#15), Bing Crosby \& the Andrews Sisters (\#13, 1939), Harry James (who adopted it as his theme song in 1940 - \#10), Frank Pourcel, Frank Sinatra and a host of actors including Jane Powell, Debbie Reynolds and Vic Damone in Hit the Deck (28).

\section{$1900 s-{ }^{`} 40 s$}

Neapolitan songs were made internationally famous first of all by opera stars like Enrico Caruso, Beniamino Gigli or Mario Lanza, but in a few cases some songs entered foreign interpreters' repertoires, as 'Torna a Surriento', recorded as 'Come Back to Sorrento' by Richard Tucker, Bing Crosby (1947) and Gracie Fields. A few years later it was Elvis Presley to cover this song with the title 'Surrender' $(\# 6,1961)$, and another pair from the classic Neapolitan songbook: 'O' sole mio' ('It's Now or Never', \#1, 1960) and 'Santa Lucia' (in Viva Las Vegas, 1964). 'O' sole mio' was also covered by Dean Martin as 'There's No Tomorrow' and by Lou Monte as 'Don't Say Forever'. But its first cover version to reach the US chart was that of Alan Turner, which in 1914 went \#9. Reed Miller's cover of 'Santa Lucia' went \#10 in 1913, even before Caruso's recording. 'O'marinariello', covered by Vic Damone and Frank Sinatra as 'I Have But One Heart', entered the US Top 20s in 1947. 'The Ferry Boat Serenade' ('La piccinina'), by Eldo Di Lazzaro, was a tremendous hit in 1940, with four versions in the charts: The Andrews Sisters (\#1), Gray Gordon (\#7), Frankie Masters (\# 12) and Leo Reisman (\#22). The year after Kay Kyser went \#6. Other versions came by Al Bowlly and The Adams Singers. 'Mama' ('Mamma') was a hit in the same year it was launched in Italy (1941) also for Horace Heidt \& His Orchestra (\#14). It was then covered in 1955 by David Whitfield (\#13) and in 1960 by Connie Francis ( 9 in UK, \#10 in USA).

'Oh What A Surprise for the Duce' ('Evviva la torre di Pisa'), a novelty song in a waltz tempo, was covered in 1940 by Florence Desmond, Bertha Wilmot and Billy Cotton \& His Band. 'Vivere', launched by the great tenor Tito Schipa in 1939, was covered as 'Romany' by Joe Loss \& His Band, Kack Harris \& His Orchestra, Lew Stone \& His Band. 'Serenade in the Night', adapted from 'Violino tzigano' (a hit by Bixio-Cherubini), was recorded in 1936 by Roy Fox \& His Orchestra, Tino Rossi, Vic Damone, Mantovani (\#7) and Jan Garber (\# 12). 'The Woodpecker Song' ('Reginella campagnola') was a big American hit in 1940: it was recorded by Glenn Miller (\#1 - on 
top for 7 weeks), the Andrews Sisters (\# 6), Will Glabe (\# 12), Kate Smith (\#14) and Joe Loss \& His Orchestra.

\section{0s}

In the fifties Italian song became more international in style and arrangement and this is proved by a few titles that sold abroad, such as two hits launched by Tony Dallara - 'Come prima' (1958) and 'Ti dirò' (1959) - covered respectively by both Malcolm Vaughan and Eve Boswell as 'More than Ever' and by Marlon Ryan, Kevin Scott and Malcolm Vaughan (\#5 UK, 1958) as 'Wait for Me'. 'Italian Theme' ('Mambo caliente', 1956), by Angelo Giacomazzi, was recorded by both Cyril Stapleton \& His Orchestra and Dorothy Collins. 'Little Serenade' ('Piccolissima serenata', 1957), by Amurri and Ferrio had covers by Percy Faith and Eddie Calvert and the same trumpeter/orchestra leader recorded 'Mandy' (\#20, UK, 1958) ('La pansé', 1957), following the examples of Edmundo Ros \& His Orchestra and The Gaylords both of whom maintained the original title. In the genre of slow ballad, 'Non dimenticar' (' $T$ 'ho voluto bene'), by Redi and Galdieri, was a hit for Nat King Cole and Connie Francis, but had several more recordings, whereas 'Souvenir d'Italie' (1956) was covered by Bob Sharples \& His Orchestra. These songs all came from Neapolitan writers and composer, as much as a long string of hits originally written in dialect like 'Blushing Moon' ('Luna rossa', 1952), covered by Alan Dean and Tony Martin, 'The Donkey Song' ('O'ciucciariello') recorded by Jane Morgan and David Carey and 'Torero', covered by Julius La Rosa (\#21 USA, 1958) and the Andrews Sisters. Its author and original interpreter, Renato Carosone, was one of the few to make it overseas, even if for a 'one chord wonder' that went \#18 in 1958. Another few songs were launched by the movies, such as 'Guaglione' ('The Man Who Plays the Mandolin'), sung by Dean Martin in Ten Thousand Bedrooms, 1956; 'Stars Shine in Your Eyes', from Fellini's La strada, recorded by both Ronnie Hilton (\#14 UK, 1955) and Eddie Barclay \& His Orchestra; 'Arrivederci Darling' ('Arrivederci Roma', 1956), with cover versions by Lys Assia, Anne Shelton, Nat 'King' Cole, Abbe Lane with Xavier Cugat and finally Mario Lanza singing in The Seven Hills of Rome; 'Anna', from the eponymous film, sung by Silvana Mangano (\#5, 1953) and covered by Jane Morgan, Ray Bloch (\#22) and Perez Prado (\#29). Anna was the first Italian blockbuster, totalling more than a billion liras and the first foreign movie to be overdubbed in the USA. In the cast there was a young Sofia Lazzaro, later known as Sofia Loren. A new, flourishing record industry was put started up by the Sanremo Festival of Canzone Italiana launched in 1951 - and the decade saw the triumphs of 'typical' Sanremo-style songs such as 'Poppa Piccolino' ('Papaveri e papere', 1953), covered by Diana Decker, Billy Cotton \& His Band, David Whitfield, The Beverly Sisters and Allan Jones; 'Chee Chee-Oo-Chee' ('Ci ciu ci cantava un usignol', 1955), covered in 36 languages, including Chinese, and a hit for Alma Cogan, the Johnston Brothers, Dean Martin and Perry Como. Its composer, Saverio Seracini, wrote the music of 'L'edera' too, recorded as 'Constantly' by Frank Sinatra, Yves Montand, Caterina Valente, Doris Day, Sarah Vaughan, Lys Assia and Cliff Richard (1964).

The biggest Italian hit ever was the song that won the Sanremo edition of 1958, 'Nel blu dipinto di blu', better known as 'Volare' from its chorus' beginning. Along with its domestic success (on top of the charts for five weeks and in the Top 40s for sixteen), Modugno's tune entered almost any of the major world markets, including the US one, traditionally hardly accessible to foreign music. The case of 'Volare' is unique in the whole Italian pop history: the author's recording topped the US charts for six weeks - from April to May 1958 - and stayed in the Top 40s for a total of thirteen weeks becoming the top song of the entire year. But with the cover versions the fame of the song grew bigger and bigger: on July 21, Billboard reviewed seven recordings of 'Volare' by different artists such as Dean Martin (\#12 in US, \#2 in UK), Nelson Riddle, Jesse Belvi, Alan Dale, Linda Ross and two Italians, Umberto Marcato and obviously the author, Domenico Modugno (also \#10 
in UK), who that year won three Grammys: Best Male Vocal Performance, Song of the Year and Record of the Year. Later came other cover versions including Charlie Drake's (\# 28 in UK, 1958), Marino Marini and his Quartet's (\#13 in UK, 1958), Bobby Rydell's (who took the song to number four in US in 1960) and Al Martino's who charted with it in 1975.

An year after, at Sanremo 1959, Modugno did it over again with 'Ciao ciao bambina (Piove)', that was covered by Connie Francis and the Four Aces but with less success.

\section{$1960 \mathrm{~s}$}

In the 1960s the Italian music industry became adult and experienced a real record boom, due to the new $45 \mathrm{rpm}$ format. The number of domestic songs that entered the international repertoire and in a few cases became classics is a big one. United Kingdom was the first and most important market for Italian covers, beginning with adult pop songs, that were appropriated by adult pop interpreters such as Engelbert Humperdinck, Tom Jones and the like. Sanremo was a hit source for Pat Boone and Joe Loss \& His Orchestra, who in 1962 covered Tony Renis' 'Quando quando quando' (29), for Humperdinck who reached \#3 with 'A Man Without Love' (originally recorded as 'Quando m'innamoro' both by Anna Identici and the Sandpipers in 1968) and for Tom Jones with 'Help Yourself' ('Gli occhi miei', both by Dino and Wilma Goich, 1968) and 'Love Me Tonight' ('Alla fine della strada', both by Junior Magli and the Casuals 1969) that went \#15 in UK and USA as well. From Sanremo came also 'The River' ('Le colline sono in fiore', both by Wilma Goich and the New Christy Minstrels), a British hit for Ken Dodd (\#5, 1966) and the winning song of 1964 edition 'This Is My Prayer' ('Non ho l'età', by Gigliola Cinquetti), recorded by Dana Valery and Vera Lynn. In the same vein the Tremeloes covered Orietta Berti's 'Non illuderti mai' that in 1967 reached \#6 UK as 'My Little Lady'. A more international flavor comes from a slow ballad such as 'Softly, As I Leave You' that was a hit for Matt Monro (\#13 in UK), Doris Day and Frank Sinatra (\#27 USA, 1964) but never reached the domestic charts in the original version 'Piano' (written by De Vita and Calabrese in 1962). Same appeal for 'How Wonderful to Know' ('Anema e core'), a Neapolitan standard from the early fifties that was covered by Joan Regan, Teddy Johnson \& Pearl Carr and Andy Williams. Another song written by Tony Renis, this time for Mina - 'Grande grande grande' - became a hit for Shirley Bassey (\#19 UK 1973) as 'Never Never Never' and was recorded again by in the late ' 90 s by Celine Dion. The swinging melodies of composer Pino Massara made it to the USA thanks to Nat King Cole, who used to open his European tours with 'Cappuccina' ('Permettete signorina', 1962) and Dean Martin, who recorded his tango song 'Grazie prego scusi', a hit for Adriano Celentano in 1963 (30). In the traditional current of slow romantic songs, one of the biggest Italian hits abroad of all times is 'Io che non vivo', by singer-songwriter Pino Donaggio, that was covered as 'You Don't Have To Say You Love Me' by Dusty Springfield (\#4 GB; \#5 US, 1965) and Elvis Presley (\#11 USA 1970) and was later recorded by Jerry Vale and by Guys ' $n$ ' Dolls in 1976. In the same vein 'I (Who Have Nothing)' ('Uno dei tanti', by composer Carlo Donida (31)) was a medium range hit for Ben E. King in 1963 (\#29) with English words by Leiber and Stoller but never entered the domestic charts. British female act Cilla Black had a long love affair with Italian songs, culminated in her recording of 'You're My World' ('Il mio mondo', by the singer-songwriter Umberto Bindi), her biggest hits ever (\#1 UK, 1964) (32). Another British act who gained their maximum exposure thanks to an Italian song was the group Amen Corner, whose 'Half As Nice' ('Il paradiso', by Lucio Battisti, 1969), was their only Number One and returned back to Top 40s in 1976 as re-issue. Talking about Brit pop and bands, the Herman's Hermits had a \#8 in UK in 1969 with 'Something's Happening' ('Luglio', by Riccardo del Turco) and a \#16 in 1970 with 'Lady Barbara' (music by Giancarlo Bigazzi, original recording by Renato), whereas the Tremeloes reached \#7 in 1968 with 'Suddenly You Love Me' ('Uno tranquillo'), 
totally absent from the domestic charts. Finally, there are a few covers from the world of soundtrack, such as the Sanremo song 'Al di là' (1962) by Frankie Fanelli (from the movie Rome Adventure) (33), 'The Legion's Last Patrol' ('Concerto disperato', 1962), by Nini Rosso and Angelo Francesco Lavagnino, that was included in the soundtrack of the eponymous film and was a British hit for by Ken Thorne \& His Orchestra (\#10, 1963) (34) and, most significantly, 'More' (music by Oliviero and Ortolani, 1963), one the biggest Italian hits ever, from the movie Mondo cane. This theme song gained a nomination for the Academy Award, NO: sold more than 4 million records all over the world and was recorded (either as instrumental or as sung version) by tens of artists among whom Danny Williams, The Mantovani Orchestra, Andy Williams, Nancy Wilson, NO: Perry Como (\#5 UK, \#4 USA), Robert Earl, Jerry Vale, Kai Winding (\# 9 USA) and Lena Horne.

\section{Sanremo: when covers returned to sender}

In the mid sixties the Sanremo Festival of Canzone Italiana experienced its most international phase, by hosting a legion of foreign artists who took part in the competition. This means that they came to sing in Italian the new songs that were tailored for them and their Italian partners by our most acclaimed writers and composers. The list is impressive and says a lot about the extent to which Italy, at the time, was taken into consideration by the global music business. The five editions of the show that go from 1964 to 1969 were an interesting experiment in linguistic and musical exchange, which tested and questioned some central issues of pop culture such as the relationship between centre and periphery, exoticism and national identity, irony and romance. All this was perceived essentially as a TV show, enlivened by the basic idea of the competition, that is, two singers - one Italian, one foreigner - would sing the same song in Italian (35). But its value as a social experiment is still to be studied. Just to give an idea of the kind of artists who participated at the time, I would like to list some of them, year after year. Beginning with 1964, as said before, Italian TV audience became familiar with Frankie Laine, Ben E. King, Antonio Prieto, Los Hermanos Rigual, Frankie Avalon, Bobby Rydell, Gene Pitney and Paul Anka. In 1965 there landed the winners of the edition, the New Christy Minstrels (including Barry McGuire), then Dusty Springfield, Connie Francis, Petula Clark, Kiki Dee, Udo Jurgens and Timi Yuro. In 1966 it was Pat Boone's turn, together with Richard Anthony, Bobby Vinton, the Yardbirds, Chad \& Jeremy, Les Surfs, Françoise Hardy, P.J.Proby and Los Paraguayos. The year after the Festival opened to the new sounds of beat and folk-rock, inviting the Hollies, Marianne Faithfull, Sonny \& Cher, Dalida, the Bachelors (who classified third), the Happenings and Los Bravos, plus mainstream singers such as Dionne Warwick, Les Compagnons de la Chanson and Bobby Goldsboro. 1968 was the Rhyhtm \& Blues year, with people like Wilson Pickett, Eartha Kitt, Shirley Bassey and a stereotyped Louis Armstrong, plus a good number of scattered artists such as Bobby Gentry, the Sandpipers, the Cowsills, Sacha Distel and Roberto Carlos, who won the competition. In 1969 we could admire Stevie Wonder, Brenton Wood, the Sweet Inspiration (with Cissy Houston) and Mary Hopkin, who classified second. It was the last time for foreign artists involved in the competition, save for a few exception in the early Seventies (the Wallace Collection and the Mungo Jerry). Twenty years later, however, the idea was taken back in the 1990 and 1991 editions, but this time the guests from abroad would sing in their languages. It was nonetheless an exciting test that furtherly proved how a poor song can be rendered by a great performer, as did Ray Charles by appropriating Toto Cutugno's 'Gli amori'. Among the stars that took part in those competitions and sang brand new Italian songs were Miriam Makeba, the Village People, Jorge Ben, Kid Creole \& the Coconuts, Nicolette Larson, the America, Leo Sayer, Dee Dee Bridgewater, La Toya Jackson, Phil Manzanera, Howard Jones, Gloria Gaynor, Ute Lemper, Bonnie Tyler, Ofra Haza, Jon Hendricks, Randy Crawford, Grace Jones, Carmel and the Moncada. 


\section{0s-today}

In the 1970s the number of cover versions diminished to the lowest level. The reason for their decline is primarily due to deep changes occurred in the estethics and geo-politics of pop, such as the fact that in Italy - as in many other countries - local musicians began to create and play their own pop/rock without the need of imitating or simply remaking Anglo-American records. Foreign artists could therefore have the absolute monopoly of their own songs in a foreign country as Italy, since competitors in the local language had almost disappeared. But in Italy an another important factor must be considered: that of SIAE, the public enterprise charged of cashing and redistributing copyright to authors and publishers. SIAE changed the rules that would assign the Italian translators a big share of the total revenues and cut it down dramatically, so that recording a foreign song in our language was not a big business anymore. An increasing familiarity that Italians started to show with the English language contributed to make more and more useless the need of having English and American hits translated. Better was buying the original. Same thing for foreign versions of Italian songs, whose number turned down dramatically, but in this case the above explanation does not apply: nobody started to buy original records outside Italy. The reasons can be various: first, the average quality of songs has lowered; second, it is not that quality songs lack, but these songs are not promoted abroad; third, even if certain cantautori are recognized as highly valuable from a qualified international public (e.g. Riccardo Cocciante and Paolo Conte are stars in France much more than in Italy; a record by Fabrizio De André has been indicated by David Byrne as the most influential of the Nineties), their songbooks do not belong to the category of 'coverable' records, being in a sense 'unique' in their original recording. There are indeed many Italian covers of these and other cantautori, but no covers in a foreign language, as far as I know (36).

However, among the few songs that stood out in the last three decades I would like to quote 'Aria' (1976), by Baldan Bembo, that had with an instrumental cover by Acker Bilk; 'Broken Hearted' ('Cuore Cuore' 1971), recorded by Ken Dodd; 'Lonely Girl' ('Non sei tu', 1974), by Adamo, covered by Eddie Holman; 'Ma cosa hai messo nel caffè' (1969), covered in 2001 by Lisa Ono, a Brazilian-Japanese singer; the 'cult' instrumental 'Mah Na Mah Na' (1977) by Piero Umiliani, \#13 in UK thanks to its being included in the Muppets' soundtrack; the dance hit 'Self-Control', by Raf, covered by Laura Branigan (\#6 US; \#9 GB, 1984) and the instrumental 'When a Child Is Born' ('Soleado', 1974), recorded by Daniel Sentacruz Ensemble, which sold 5 millions in Italy and all over the world also thanks to Johnny Mathis' version (\#5, 1976).

\section{Cultural mediators}

Apart from opera, Italian music has never had a big penetration on foreign markets. The number of records (i.e. cover versions and original Italian songs) that entered British and American Top 40s does not exceed a hundred. The only significant case in the field of popular music is represented by the diaspora artists, from Enrico Caruso to Ray Gelato, from Gilda Mignonette to Lou Monte: artists who migrated abroad or were born in a foreign country from Italian parents. They represent an important section in the cross-cultural dynamics I am trying to map out, for they not only covered foreign songs in Italian and viceversa but, most importantly, they were the first real ambassadors of a musical culture.

Even though Europe played its role in this respect, with relevant French mother tongue artists such as Adamo (Salvatore Adamo), Nino Ferrer (Agostino Ferrari), Herbert Pagani and Dalida (Jolanda 
Gigliotti) - to quote just the most famous - the diaspora story is mainly an American one, from North to South. In Southern America immigrants from Italy gave a strong contribution to the birth of tango but were soon assimilated by a new cultural mix. In Northern America, along with a majority of immigrant artists who assimilated local costumes, there has always been a minority who has maintained strong relationships with the country of origin and perpetuated its traditions. Singers such as Jimmy Roselli, Dean Martin (Dino Crocetti), Perry Como (Pierino Como), Frank Sinatra, Louis Prima, Connie Francis (Concetta Maria Rosa Franconero), Mario Lanza (Alfred Arnold Cocozza), Jerry Vale (Gennaro Louis Vitaliano), Julius La Rosa and Lou Monte (Louis Scaglione), 'the king of Italian-American hit records', recorded a good number of Italian and Italian-style songs, sometimes in English, sometimes in Italian or Neapolitan, sometimes in all of these languages.

On the contrary, the presence of foreign songs covered in Italian is a huge one. British and American music hold the biggest share, but also very high is the number of French and LatinAmerican and Spanish songs. In this final part of the article I would like to focus on a few recordings that are more than simple 'cover versions' and end up with being real 'remakes' of the original. An original which sometimes is a mediocre song destined to be forgotten or which does not meet its first public's expectations but can seduce a second public in a foreign country.

Cover bands had an easy job to perform in the sixties, when tons of English and American records arrived in Italy: it was enough to pick up a hit record and translate it, to be successful. And this was the rule for hundreds of meteors that did not leave any signs of their passage. In a few cases, however, the job required a higher level of sophistication and risk, when the band would choose in a minor songbook and succeeded in transforming a minor track into a hit sung in a language different from the original. This occurred, e.g., with 'Come potete giudicare' by the Nomadi, which turned 'The Revolution Kind' into a generational anthem. The protest ballad by Sonny Bono was virtually unknown until the most enduring rock band in Italy to date picked it up in 1966 to deliver it to History... The same occurred to the Rokes' ' $E$ ' la pioggia che va', the second cover version of a Bob Lind song recorded by this band of British immigrants (37). Bob Lind was a twenty year old folksinger from Baltimore who did write nice songs but never really made it in fatherland. He must thank the Rokes, but first of all the lyricist Mogol, if his 'Remember The Rain' went number one in Italy and soon became one of the cult record of the Beat era. The song was also covered by Caterina Caselli who, incidentally, recorded 'Elusive Butterfly', the only international hit by Bob Lind, with the title 'La farfalla'. Caterina had a special flair for picking up obscure B-sides and turn them into gold (38), as it happened in 1968 with 'The Days of Pearly Spencer', a fine song penned by David McWilliams which was totally ignored at the time. A typical product of the 'flower power' season, this song was restyled with string arrangements and the voice treated with a megaphon-like filter, whereas the record - titled 'Il volto della vita' - was packed with a classic psychedelic cover. Final result: it went number two in the domestic charts. Curiously enough, the original song came back in 1992 thanks to a cover by Marc Almond (\#5 in UK) and that was the first time 'The Days of Pearly Spencer' had the honor of entering charts other than Italian.

With 'Cuore', one of the biggest hits by Rita Pavone and sixth record in 1963 as to copies sold, the confrontation with the original is overwhelming: Heart was a minor song of the fortunate team formed by Barry Mann e Cynthia Weill. The authors passed it to the debuting Wayne Newton, an American teenager who was Rita's same age, but the move was nearly a flop so that, after the domestic success, Rita recorded and English version too and this time her 'Heart' broke into English charts conquering the spot number 26 in 1966. A similar story happened to Italy's greatest female voice, Mina, who in 1964 covered 'He Walks Like A Man', a minor song recorded by Jody Miller that never entered any charts, whereas 'E' l'uomo per me' (the Italian title) turned into a chartbuster that topped the domestic charts for four weeks. 
Other significant cases are, at last, those of Ornella Vanoni and Milva, two sophisticated ladies of canzone, who in their careers have recorded several foreign songs from Brazilian, French and German repertoires. Ornella's strict collaboration with Toquinho and Vinicius De Moraes made her their muse in Europe, more or less as Dionne Warwick was Bacharach's and David's ideal interpreter. As to Milva, she started covering Edith Piaf's songs in 1960, when her 'Milord' topped the charts in Italy. Then she devoted herself to art song, becoming a star in Germany where she regularly sings Brecht's and Weill's songbook - both in German and in Italian. A third female voice of the 1960s, Iva Zanicchi, recorded an album of Miki Theodorakis' songs that had a tremendous success, so that also Greek author's music broke into the collective musical consciousness of my country.

The story stops here. Why, should I ask, there are no Japanese, no Scandinavian, no East-European songs covered in Italian? When this happened, very rarely, the visibility and worldwide success of tunes coming from peripheral countries was due to Hollywood or to a music business still based in the Anglo-Saxon world, and not from countries that have no power to mould international products yet. Therefore, the study of repertoire exchange - what are the most diffused, and thus the most covered songs - is ultimately a study of the world music and culture market from a geopolitical perspective and it can probably shed a light on the persistence of influences and cultural patterns which a country like Italy imported from abroad and assimilated in various measures. In particular, the study of Italian songs that have been covered in foreign languages can shed a light on the power/authority of this country to count in the international culture market.

For example, it is more likely that a song born in Italy goes South-American or Albanian than English.

\section{Conclusion}

Along with being a laboratory of esthetic experimentation, cover versions play an important role in the economics and geopolitics of popular music. This role became crucial when music industry shifted from a sheet-centered to a record-centered orientation. In the Tin Pan Alley era, as a matter of fact, many interpreters at the same time had the chance of appropriating a song that was originally made available in form of notation and so was often its arrangement, with the result that the various recorded versions of the song differed from one another only for the timbre and style of singing and playing. With the advent of Rock ' $n$ ' Roll - to simplify - the author tended more and more to coincide with the performer and his/her recorded performance was considered to be the original version of the song, so that a second artist who would want to record the same song did not simply made another version of a neutral 'text' available to anybody in an abstract form (i.e. as notation) but 'covered' that particular performance heard on record. In other words, the latter's authority was such that any subsequent cover had to be confronted with the original version, whereas in the Tin Pan Alley tradition there were no originals in theory, being all versions legitimate. In the same vein I have looked at the covers versions in another language (namely Italian), a case in which the original's authority is even stronger, due to what has to be seen as a power relationship, that is a relationship between a dominant language (English, sometimes French and Spanish) and a peripheral one (Italian). Nevertheless, after testing the supposed validity of the 'cultural imperialism thesis', I have opted for a different kind of explanation, rooted in my generation's direct experience: in those 'second hand' versions, people did not feel a sense of cultural domination but, on the contrary, a new exciting drive. And for many it was even more: a message of liberation from the old schemas in which music and artistic expression was constrained. This 'kind of magic' occurred in a very narrow span of time: cover versions had been indeed recorded for a long time in Italy, but they did never represent more than 'just new songs'. If, on a 
broader level, I see the cover version as a cross-cultural device that puts into communication two or more cultures and creates a virtual international community tied together by the same songs, in particular, what happened in Italian mid-sixties had an added value that turned an ordinary practice in the music business into a social phenomenon: a thing that I have ironically tagged the Big Cheat, but a thing that paved the way to modern Italian song. This phenomenon, if you like, contained the very contradictory essence of modern popular culture: it was global and local, artificial and sincere and it took over thanks to both cultural moves from below and economic/juridical rules from above.

\section{Notes}

1. The Festival, which has been taking place since 1951 once a year, is the bigger stage for Italian song: during that week between February and March Italy is almost swept by a music craze, newspapers report on the competition in their front pages, TV news open on Sanremo, radios change their playlists to give room to the new songs. It is the only time in which a mass product rated traditionally as 'low-brow' crosses over to public debate, reaching people who usually were not interested in it. At the same time, Sanremo is first of all a TV show, whose impact on the record industry is largely uninfluential. See Borgna (1998) and Prato (2005b).

2. 'Cheryl's Goin' Home' is the title of another different song written by Sonny Bono.

3. See Various Artists, O melhor da jovem guarda, Columbia 850.173/2-464314. Brazil.

4. I am grateful to Shuhei Hosokawa for this information on Brazil and Japan.

5. Laura Pausini is the second Italian artist of all time to win a Grammy Award, after Domenico Modugno in 1958, the year the Award was started. But her Grammy went to a Spanish cover of her own Italian album and not to the original version. Laura owes therefore her worldwide fame to Latin culture and market: her Italianity would not have been enough to reach the same level of popularity.

6. Noah has been long flirting with Italian music, since she recorded Grammy Awarded song 'La vita è bella' (from Nicola Piovani) and tours regularly in the country, also as peace ambassador.

7. The centre-periphery dichotomy reflects the notion of an abstract imperial system where power and richness are distributed in a concentric fashion and gradually decrease from centre to periphery (Canclini 1990).

8. Deterritorialization occurs when culture loses its natural relationships with its geographic and social origins. Reterritorialization, on the contrary, is the (partial) refoundation of old and new symbolic practices. This distinction does not totally fit in the case of cover records: losing its original language - e.g. from English to Italian - does not mean to remove completely its original territory for this remains part of the record intrinsically, but nevertheless it may cause confusion, a sense of displacement as it occurred to many music fans of my generation who thought that many of those cover records in the 1960s were Italian songs, born in Italy and written by Italian authors simply because they were recorded in Italian.

9. Campbell Robinson, D. - Buck, E. B. - Cuthbert, Marlene and the International Communication and Youth Consortium. 1991, p. 108 (text by Jody Berland, Will Straw, Paul Rutten and Georgette Wang).

10. Jaak Ojakäär, Estonia, in EPMOW, volume VII, pp.3-8; Tamás Szõney and Júlia Lévai, Hungary, in EPMOW, volume VII, pp.24-39.

11. Claire Levy, Bulgaria, in EPMOW, volume VII, pp-102-088; Svanibor H, Pettan, Croatia, in EPMOW, volume VII, pp-109-112.

12. Dave Laing, Austria, in EPMOW, volume VII, pp.144-147; Pekka Jalkanen, Finland, in EPMOW, volume VII, pp.161-168; Hans Weisethaunet, Odd Skårberg, Norway, in EPMOW, volume VII, pp.270-287.

13. Francisco J. Garcia Gallardo, Herminia Arredando Pérez, Spain, in EPMOW, volume VII, pp.288315.

14. Joanna C.Lee, Hong Kong in EPMOW, volume V, p.34. 
15. Okon Hwang, South Korea, in EPMOW, volume V, pp.45-51.

16. Tan Sooi Beng, Malaysia, in EPMOW, volume V, pp.186-196.

17. Latin music offers a different view on the globalization of local music. A lot of latin genres have gone popular in many African countries, beginning with the 1950s and the boom of dances such as cha cha, mambo, bolero in Congo (Chris Stapleton, Congo, in EPMOW, volume VI, pp.23-26), in Tanzania and Uganda.

18. Jonas Baes, Philippines, in EPMOW, volume V, p.209.

19. Dave Laing, Singapore, in EPMOW, volume V, pp-221-214; John Clewley, Thailand, in EPMOW, volume V, pp.214-221,

20. Dave Laing, Algeria, in EPMOW, volume VI, p.65.

21. João Soeiro de Carvalho, Mozambique, in EPMOW, volume VI, pp.94-97.

22. Chris Stapleton, Zimbabwe, in EPMOW, volume VI, p.119.

23. Seyed Abdolhossein Mokthabad Amrei, Iran, in EPMOW, volume VI, p.207.

24. Toru Mitsui, Japan, in EPMOW, volume V, p.143.

25. Risto Pekka Pennanen, Greece, in EPMOW, volume VII, pp.114-124.

26. Peter Wicke confirms this trend in what was once East Germany, where "the Anglo-American form of rock also took the GDR by storm in the sixties, and its spontaneous adoption by young amateur groups coincided, just as in the US and Great Britain, with innovations in media technology and farreaching changes in the social patterns of media use' (Wicke 1985, p.321).

27. For those who can read Italian, I would like to quote a book of mine (Prato 2001) which deals precisely with these more common covers.

28. Except when otherwise indicated, the number indicated between brackets stands for the highest position obtained by the record in the US charts.

29. In the disco era the song was re-covered in English by the author as Disco Quando and in 2005 it was recorded in English by Michael Bublé featuring Nelly Furtado.

30. 'Cappuccina' was recorded also by the Japanese acts Danny Lida \& Paradise King in the same year as Nat King Cole.

31. In 1960 Donida had a hit in UK with 'Mais qui' (\#19) recorded by the King Brothers.

32. Cilla Black covered a few minor hits as well such as 'A Fool Am I' ('Dimmelo parlami', 1966) and 'Don't Answer Me' ('Ti vedo uscire', 1966).

33. Emilio Pericoli's original recording of 'Al di là', also included in the same movie, reached \# 6 I the USA charts.

34. Another instrumental written by the trumpeter Nino Rosso called 'Il silenzio' (1965), was recorded by Eddie Calvert.

35. With a few exceptions: Wilson Pickett, for example, sang 'Deborah's verse in Italian but the chorus in English.

36. A few cantautori, for example Franco Battiato, have tried to enter the US market by recording their songs in English, but their records were all flops.

37. The first was 'Cheryl's Going Home', as already said.

38. Once she left performing in the early 1970s, Caterina Caselli turned into a manager and talent scout, soon becoming the most important woman in Italian record industry. She is the one who discovered and launched, among others, the career of Andrea Bocelli. 


\section{Bibliography}

Adinolfi. F. and Prato, P. 2005. 'Italian Diaspora', in Encyclopedia of Popular Music of the World vol.VII (London-New York), pp. 252-256.

Alberoni, F. 1966. 'La cultura di massa', in AA.VV., Questioni di sociologia (Brescia), pp.95-124.

Appadurai, A. 1996. Modernity at Large: Cultural Dimensions of Globalization (MinneapolisLondon).

Beretta, F. (ed. by). 1993. Piccolo Dizionario delle cover del Bitt (A Small Dictionary of Beat Covers) in Rizzi, C. (ed. by), Enciclopedia del Rock Italiano (Enciclopedia of Italian Rock) (Milan).

Borgna, G. 1998. L'Italia di Sanremo (Sanremo's Italy) (Milan).

Boyd Barrett, J.O. 1977. 'Media Imperialism. Towards an International Framework for an Analysis of Media Systems', in J.Curran, M.Gurevitch and J.Woolacott (eds.), Mass Communication and Society (London), pp-116-135.

Bronson, F. 1988. The Billboard Book of Number One Hits (New York).

Campbell Robinson, D. - Buck, E. B. - Cuthbert, Marlene and the International Communication and Youth Consortium. 1991. Music at the Margins. Popular Music and Global Cultural Diversity, (Newbury Park-London-New Delhi).

Canclini, N. G. 1990. Culturas hibridas. Strategias para entrar y salir de la modernidad (Hybrid Cultures. Strategies for Getting In and Out of Modernity) (Mexico City).

Garnham, N. 1984. Introduction. A.Mattelart, X.Decourt and M.Mattelart, International Image Markets (London).

Guinness British Hit Singles (13 ${ }^{\text {th }}$ edition). 2000. (London).

Keightley, K. 2003. 'Cover version', in Encyclopedia of Popular Music of the World, vol.1, (London-New York), pp-614-617. 
Laing, D. 1986. 'The music industry and the 'cultural imperialism' thesis', in Media, Culture and Society 8 no.3, pp.331-341.

Lowe, L. 1992. Directory of Popular Music (London).

McAleer, D. (comp.by). 1994. The Warner Guide to UK \& US Hit Singles ( London) .

Padovano, R. 1997. Hit Parade (Milano).

Pareles, J. and Romanowski, P. (ed. by). 1983. The Rolling Stone Encyclopedia of Rock ' $n$ Roll. (New York).

Prato, P. 1988. 'Tradition, Exoticism and Cosmopolitism in Italian Popular Music', Differentia 2, pp-195-218.

Prato, P. 1993. 'Sanremo anni '60' (Sanremo, the Sixties), in P. Prato, Musica \& Musica 17 (Roma). (no page numbers, since it's a partwork publication for the kiosk, not a journal)

Prato, P. 1996. 'Italiani' (Italians), in P. Prato, Dizionario di Pop \& Rock (Pop/Rock Dictionary) (Milano), pp.167-169.

Prato, P. 2001. Le più belle canzoni straniere cantate in italiano (The Most Beautiful Foreign Songs Sung in Italian) (Milano).

Prato, P. 2005a. 'Naples', in Encyclopedia of Popular Music of the World vol.VII (London-New York), pp-243-247.

Prato, P. 2005b. 'Sanremo, in Encyclopedia of Popular Music of the World vol.VII (London-New York)., pp.250-251.

Schiller, H.I. 1976. Communication and Cultural Domination (New York).

Shannon, B. and Javna, J. 1986. Behind the Hits (New York).

Tunstall, J. 1977. The Media Are American. Anglo-American Media in the World (London).

Wallis, R. - Malm, K. 1984. Big Sounds from Small Peoples. The Music Industry in Small Countries (New York)

Whitburn, J., 1986. Pop Memories 1890-1954 (Menomonee Falls).

White, L.A. 2001. 'Reconsidering cultural imperialism theory', in TBS Archives no.6, Spring/Summer. (page numbers not available, as found on the Internet)

Wicke, P. 1985. 'Young People and Popular Music in East Germany: Focus on a Scene', Communication Research vol.12 no.3 ,July., pp-319-325. 


\section{Discography}

Francis, Connie. Italian Collection vol.I. Polygram Records 31453 9556-2. 1997: USA.

Martin, Dean. Dino (Italian Love Songs). Capitol Records T-1659. 1961: USA.

Milva, La Chanson Française. Agorà, AG288.1. 2001: Italy.

Mina, Colecciòn latina. EMI. 532665 2. 2001: Italy.

Monte, Lou. The Very Best Of. Taragon Records 1030. 1997: USA.

Roselli, Jimmy. Italian Album. M \& R Records 1005. 1970: USA.

Vale, Jerry. Sings The Great Italian Hits. Sony Music 65674. 1998: USA.

Vanoni, Ornella. La voglia la pazzia l'incoscienza l'allegria. RCA 2108001. 1976: Brazil

Various Artists. Band in Italy - Italian Beatles. De Agostini, BANO2BIS. 2003: Italy

Various Artists. Le più belle canzoni straniere cantate in italiano. Selezione dal Readers' Digest, 2001: Italy (CD enclosed to Prato 2001)

Various Artists. Neroitaliano. Quando in Italia si cantava il rhythm \& blues, Motown, ZL 72631. 1988. Italy

Various Artists. O melhor da jovem guarda, Columbia 850.173/2-464314: Brazil.

Various Artists. Eh, Paisano! Italian-American Classics. Rhino Records 72577. 1997: USA.

Various Artists. Mob Hits (Double CD). Triage Entertainment 96401. 1999: USA 